\title{
LOS ANIMALES EN LA LITERATURA
}

\section{María Luzdivina Cuesta Torre (COORdinadora y editora)}

Con este monográfico, que recoge una serie de artículos sobre la presencia de los animales en la literatura, se inicia una nueva sección de la revista Lectura y Signo, destinada a ofrecer una serie de estudios sobre un tema literario determinado, sobre una técnica literaria o sobre una época, estilo o tendencia literaria. En esta primera ocasión el tema elegido ha sido la presencia de los animales en la literatura. El importante número de artículos recibidos ha hecho necesario dividir el monográfico en dos partes, de las cuales se publica en este número la primera, siendo el género fabulístico el que sirve de nexo de unión para los diferentes estudios aquí recogidos. Quedan para su edición en la segunda parte de este monográfico aquellos artículos que tratan acerca de los animales con independencia de este género literario, los cuales, tras su evaluación positiva por pares, se publicarán en el número del próximo año.

Efectivamente, tanto los géneros dramáticos, como la lírica y los numerosos géneros narrativos han acogido la presencia de esta temática a lo largo de los tiempos, ya sea de forma realista, como imitación de los animales del mundo real, ya sea de forma simbólica, surrealista, expresionista... bien como personajes, bien como objetos de comparación o términos de metáforas, bien con valor alegórico. En cualquier caso, los animales de papel y tinta, los animales literarios construidos con palabras, ocupan un lugar destacado y muestran la importancia de la relación del ser humano con la naturaleza y más específicamente su pertenencia al reino animal en el que, a través de la descripción del comportamiento de otras especies, se descubre a sí mismo.

Entre los géneros protagonizados por animales destacan de forma especial el cuento de animales, ya sea de tipo tradicional, ya sea en su vertiente culta dentro de la literatura infantil, y la fábula, cuyo propósito ejemplificador ha propiciado su inclusión en la didáctica y, con ello, su utilización a menudo en programas de estudio dedicados a la infancia, tanto por su contenido moralizador (especialmente desde que se añade a su estructura la sentencia final), como por su concisión, que la hacía útil para los ejercicios escolares. En su origen la fábula, sin embargo, se encuadra plenamente en la literatura para adultos y Aristóteles la describe entre los recursos retóricos que debían servir para convencer en la discusión judicial o política. La fábula poseía la ventaja, sobre el ejemplo tomado de un caso real, de poder ser inventada a la medida de las 
necesidades argumentativas del momento. Fábula, ficción y discurso argumentativo se encuentran estrechamente unidos, de ahí que fabular sea mentir y que fábula y habla deriven de la misma palabra latina. Pero la ficción, la mentira literaria, revela las más profundas verdades, y así lo entendieron tantos escritores, de diversas épocas, que fingieron que los animales hablaban para poder decir a través de su boca lo que podía conllevar censura o desgracia al emisor humano del mismo mensaje. Con más de dos mil quinientos años de historia, la fábula demuestra que el conocimiento sobre la persona humana que aportan los animales literarios sigue sintiéndose como necesario en diferentes épocas y culturas.

Los estudios aquí recogidos se presentan en el orden en que fueron aceptados para su publicación y abarcan aspectos muy diferentes de la fábula. Varios inciden en la literatura medieval: la presencia de temas de la fábula mitológica relativos a un animal determinado (la comadreja) en los bestiarios medievales, las obras catalanas del siglo XIV en las que caballos y asnos se atreven a criticar a los humanos y a reflexionar sobre su comportamiento, o el análisis de los proverbios y sentencias del Livro de Exopo portugués del siglo XV. Otros artículos abordan la in luencia de los esopetes en los siglos siguientes, en los que se hace sentir en ámbitos tan diferentes como la edición barroca del fabulario indonesio en portugués de Batavia y en las menciones a temática fabulística en obras teatrales castellanas del Siglo de Oro. La recuperación del fabulario sefardita, tan ignorado hasta fechas recientes, es otra muestra más de esta pervivencia del género a través del tiempo y de distintas lenguas y culturas. Otros abordan el empleo de la fábula en la enseñanza, incidiendo en los distintos aspectos en los que favorece el desarrollo intelectual, lingüístico, literario y retórico del niño, o describen su uso como literatura satírica subversiva, con un marcado propósito de crítica y de cambio social.

El conjunto trae a los lectores un conocimiento más amplio de la variedad y unidad del género fabulístico y de su importancia y repercusión social, cultural, educativa y literaria, al constituirse en intertexto que traspasa fronteras genéricas (mitología, bestiario, proverbio, teatro).

La edición y coordinación de este Monográfico no hubiera sido posible sin la ayuda del Ministerio de Economía y Competitividad del Gobierno de España, puesto que se ha realizado en el marco del proyecto MEC FFl-2012-32265, dedicado al estudio de la fábula española del siglo XIV. 